\title{
Antimalarial, Antitrypanosomal, Antimicrobial Activities and Volatile Oil Profile of Xylopia aethiopica (Dunal) Rich
}

\section{(Annonaceae)}

\author{
Larayetan Rotimi Abisoye 1,*(D) \\ 1 Department of Pure and Industrial Chemistry, Kogi State University, Kogi State, Anyigba, Nigeria \\ * Correspondence: timlarayetan @ gmail.com (L.R.A.);
}

Scopus Author ID 57194439696

Received: 1.04.2021; Revised: 15.07.2021; Accepted: 18.07.2021; Published: 12.09.2021

\begin{abstract}
The resistance of Plasmodium falciparum ( $P$. falciparum) to well-recognized antimalarial drugs is now common in nearly every area of its prevalence; consequently, there is a need to explore therapeutic plants that have bioactive compounds which can be utilized in the manufacture of antimalarial drugs. The in vitro potency of the volatile oil (VO) of Xylopia aethiopica (X. aethiopica) was evaluated against $P$. falciparum 3D7 strain, a human malaria parasite, a good activity against the parasite $P$. falciparum was recorded with an IC50 of $14 \mu \mathrm{g} / \mathrm{mL}$. The in vitro cytotoxicity of the fruit oil of $X$. aethiopica was determined at a concentration of $50 \mu \mathrm{g} / \mathrm{mL}$ against HeLa cells and was found to show no cytotoxicity effect at this concentration; this could be an indication of the safety of the fruit oil as a targeted drug for mammalian organisms., The antibacterial property of the VO from the fruit of $X$. aethiopica, was evaluated in vitro; the fruit oil exhibited good antimicrobial activity against the tested microorganisms, with Klebsiella pneumoniae having the highest inhibition zone of $19.0 \pm 1.4 \mathrm{~mm}$. The result recorded for MBC/MFC confirms that VO of this plant can be used in therapeutic preparations, particularly in the infections brought about by some of these microorganisms as practiced by traditional healers in folkloric medicines. This appears to justify the numerous folkloric therapeutic uses of the aerial parts of this plant. The hydro distilled volatile oil from X. aethiopica was characterized by Gas Chromatography-Mass Spectrometry (GC-MS), an abundance of monoterpenes hydrocarbon (58.0\%), followed by oxygenated monoterpenes $(30.13 \%)$, sesquiterpene hydrocarbon $(8.96 \%)$, and fatty acid $(0.74 \%)$ were well represented. The significant quantitative constituents of the fruit oil are 1,8 -cineole (16.73\%), $\beta$-pinene (11.59\%), sabinene (10.76\%), 1R- $\alpha$-pinene (8.30\%), $\alpha$-phellandrene (8.34\%).
\end{abstract}

Keywords: Xylopia aethiopica; antimalarial; antimicrobial screening; hydro distillation; volatile oil.

(C) 2021 by the authors. This article is an open-access article distributed under the terms and conditions of the Creative Commons Attribution (CC BY) license (https://creativecommons.org/licenses/by/4.0/).

\section{Introduction}

Great emphasis has been placed on herbal drugs used for human health care by the World Health Organization (WHO); this organization has printed different policies guiding principles and criteria for these botanical drugs [1]. Investigation into bioactive compounds obtained from plants as a source of alternative medicine to synthetic drugs have received much awareness and attention from natural product chemist all over the globe; this is because therapeutic plants have been discovered to possess several medicinal properties useful in the management of many ailments with little side effect when put side by side with synthetic drugs [2]. The main cause of malaria infection is the Plasmodium parasite; they contaminate the red blood cells (RBC) and bring about symptoms like pain, chills, fever, and sometimes swelling. 
Many modern drugs like Artemisinin and Quinine are derived from a plant used to treat malaria [3]. The problem of resistance to some known drugs, particularly chloroquine, is one of the greatest problems about malaria control in this present day time [4,5]. Chloroquine which was very cheap and effective against malaria parasites in the past, is now considered ineffectual due to multiple resistant poses by $P$. falciparum to this drug [6]. As a result of this resistance menace, malaria eradication is becoming increasingly difficult since the disease usually resurfaces in areas where it had been originally stamped out and emerges in formally unaffected vicinities. The resistance of $P$. falciparum to well-recognized antimalarial drugs is now common in nearly every area of its prevalence [7]. Therefore, there is a call for serious efforts to develop a new antiplasmodial drug from plants; all researchers of natural products are thereby encouraged to exert their precious time and energy into medicinal plants with antimalarial potencies by screening a large number of therapeutic plants from different tribes and rural areas where these medicinal plants have been reported to have great efficacy against $P$. falciparum parasite. If the antiplasmodial effect of these plants can be established after the necessary screening, the bioactive compounds responsible for the antiplasmodial activity can be isolated via a range of extraction methods.

Xylopia aethiopica is a sweet-smelling therapeutic plant frequently found in the extreme forest-Savanna zone of Africa or the lowland rainforest region of Africa; this plant can reach about twenty meters high [8] and is classified among the Annonaceae family [9]. This evergreen plant is commonly seen in African countries like Gambia, Kenya, Togo, Sierra Leone, Liberia, Burkina Faso, and Nigeria $[10,11]$. The fruit of X. aethiopica is greenish when freshly harvested but brownish dark when dried; the peppery taste and the strong "pepperish note from the fresh fruit of $X$. aethiopica are largely due to "linalool" one of the volatile constituents of the oil, this constituent is responsible for the characteristic aroma of the ground, dried and smoked fruit of the plant [9]. The pods of this plant contain about 5-8 seeds; the fruit looks like cowpea pods with constriction along their length; the pod never split open to release its seeds. It is a plant of great repute in Africa, the wood obtained from this plant has been documented to be resistant to termite attack. As a result, the bark of the plant is used to make doors and partition, and also used in the construction of huts in rural African settings [12]. Barely every morphological part of $X$. aethiopica, like the leaves, stem, root, stem bark, and fruit (both dried and fresh), are used in traditional medicine to treat various diseases, including rheumatism, headache, malaria, asthma, epilepsy, infertility, dysentery, skin infections, candidiasis, ease of dyspepsia, cough, fever, and moderate anti-SARS-CoV-1 and SAR-CoV2 infection [12-15]. Its anticancer, antimalarial, antidiabetic, antioxidant, enzyme inhibition, and antimicrobial potencies have been documented [13]. The plant is commonly referred to as African Pepper" (English name), "Ethiopian Pepper" or "Guinea Pepper, it is also referred to as 'Eru' in the South Western part of Nigeria [12].

Infusion obtained from the bark of the plant is employed in the treatment of bronchitis and dysenteric conditions or as a mouth wash to treat toothaches, used to reduce rheumatism pain [4], used as an insecticide to control insects, used in meat and food preservation, [10, 16], used in the management of neuralgia, headache, colic pain [17], to treat male infertility [18]. It was documented from previous research findings that extract derived from the fruit, when taken orally, can boost steroid hormone and sperm count [19]. Combination of extract from this plant with an extract from New-boudin leaves (Bignoniaceae) plant was used some time ago in hospitals owned by Ghana Government to enhance menstrual flow and induce placental discharge during post-partum due to its abortifacient properties $[12,17]$ while powered derived 
from the root of $X$. aethiopica was used as dressing for sores and engaged in the local treatment of cancer [20]. A decoction from the root and leaves of this plant is commonly referred to as 'Agbo' in South-Western Nigeria, while the power from the root, when combined with salt, is used to treat constipation [21]. The fruit obtained from $X$. aethiopica is an important ingredient in the Eastern part of Nigeria used to prepare local soup believed to aid the easy flow of breast milk from breastfeeding mothers. Different extracts from the aerial parts of $X$. aethiopica have been used as an adjunct therapy to treat sickle cell disease [22]. Thus, X. aethiopica is an essential item in Africa used majorly for spice, medicine, and flavoring.

As a result of the efficient antimicrobial activities displayed by $X$. aethiopica in traditional settings, researchers embarked on the in vitro antimicrobial test to ascertain these claims. Konning et al. [23] investigated the antimicrobial efficacy of the methanol extract of this plant and found out that the extract was active against both Gram-positive and Gramnegative bacteria with excellent antifungal activity against Candida albicans and Aspergillus niger while Alfred et al. [24] worked on the antimicrobial activity of the dichloromethane/methanol extract from the seed of the plant, it was documented by this researcher that the extract showed positive activity against $S$. aureus ATCC 25923, C. albicans ATCC 10239, E. coli ATCC 25922, C. violaceum CV 12472 and P. aeruginosa PA 01 with same MIC values of $0.625 \mathrm{mg} / \mathrm{mL}$ for $S$. aureus ATCC 25923, P. aeruginosa PA 01 and $C$. albicans ATCC 10239, and same MIC values of $2.5 \mathrm{mg} / \mathrm{mL}$ for E. coli ATCC 25922 and $C$. violaceum CV 12472. Several reports of the antimicrobial activity of the volatile oil from the plant of study have been reported in the literature; the volatile oil, as well as the crude extract (both alcoholic and aqueous) of the plant, have been shown to have a wide range of activity against Gram-positive, Gram-negative bacteria and Candida albicans [18, 25-27].

The commonest bioactive compound present in the different parts of $X$. aethiopica is the terpene constituents found in the volatile oil of the plantyt6. Several studies have been carried out on the volatile oils from this plant; they have displayed the presence of a broad diversity of chemical compounds. In one such study conducted in Togo thirty-five constituents were found in the volatile oil with major constituents as $\beta$-pinene $(23.6 \%), \alpha$-pinene $(11.0 \%)$, sabinene $(9.80 \%)$, germacrene D $(8.30 \%)$, and 1,8 - cineole $(8.20 \%)$ [28], while the oil from Mali was rich in $\beta$-pinene (19.1\%), $\gamma$-terpinene (14.70\%), trans-pinocarveol $(8.60 \%)$ and $\rho$ cymene $(7.30 \%)$ [29].

Therefore this present work seeks to evaluate the volatile oil from the crude extract of $X$. aethiopica fruit oil as an alternative herbal medicine to curb plasmodial parasite and some microbial diseases; since this plant is used in folk medicine for various therapeutic purposes, their volatile oil is likely the reasons for their different medicinal values.

\section{Materials and Methods}

\subsection{Plant material and essential oil isolation.}

The matured seeds of $X$. aethiopica were obtained from their natural habitat in the Ogugu area of Kogi State of Nigeria. Identification was made at the Department of Botany, Kogi State University, Anyigba, Nigeria. Vouchers specimen was deposited at the University herbarium. The fruits were macerated using a fast rotating blender and subjected to hydrodistillation using Clevenger-type apparatus. GC-MS analysis was immediately carried out on the extracted volatile oil. 
2.2. Gas chromatography/mass spectrometry analysis.

The fruit oil of $X$. aethiopica was analyzed using multidimensional gas chromatography coupled with a gas chromatography-mass spectrophotometer (Shimadzu Japan, 2010) equipped with non-polar and polar double capillary columns $(25.0 \mathrm{~m} \times 0.25 \mu \mathrm{m}$ i.d., $0.25 \mu \mathrm{m} \mathrm{df})$. The carrier gas used was helium of high-level purity at a constant flow rate of $0.99 \mathrm{~mL} / \mathrm{min}$. The oil sample of $1 \mu \mathrm{l}$ volume was injected at a split ratio of 41.6 into the GC and GC/MS with an AOCZOi auto-injector. The starting temperature of the instrument was set at $60{ }^{\circ} \mathrm{C}$ (held for $1 \mathrm{~min}$ ), heated at a rate of $10^{\circ} \mathrm{C} / \mathrm{min}$ to $180^{\circ} \mathrm{C}$, held isothermally for 3 minutes, and then at $12^{\circ} \mathrm{C} / \mathrm{min}$ to $280^{\circ} \mathrm{C}$ (finally held for $2 \mathrm{~min}$ ). Ion source and transfer line temperatures were set to $200{ }^{\circ} \mathrm{C}$ and $250{ }^{\circ} \mathrm{C}$, respectively, while a solvent delay of 3 minutes was observed. Electron impact (EI) ionization mode was $70 \mathrm{EV}$, and the linear velocity of the column was $36.2 \mathrm{~cm} / \mathrm{sec}$. Based on their mass spectra, various components were identified compared with those available in the NIST Library Mass Spectra database and mass spectra from literature. [30].

\subsection{Tested bacteria and fungus strains.}

Escherichia coli (E. coli), Klebsiella pneumoniae (K. pneumoniae) Pseudomonas aeruginosa (P. aeruginosa), Salmonella typhi (S. typhi) (Gram-negative bacteria), Staphylococcus aureus (S. aureus), Bacillus subtillis (B. subtillis) (Gram-positive bacteria and Candida albicans (C. albicans) (Yeast like fungus). These organisms were collected on sterilized nutrient agar slants, and incubation was carried out at $37^{\circ} \mathrm{C}$ for a day.

\subsection{Antimicrobial screening.}

\subsubsection{Zone of inhibition-agar well diffusion method.}

The antimicrobial efficacy of the volatile oil of $X$. aethiopica was determined using seven pathogenic microorganisms (clinical bacterial isolates) obtained from the Microbiology Section (Environmental Technology Division) of the National Research Institute for Chemical Technology, Zaria. According to the National Committee for Clinical Laboratory Standard [31], Agar well diffusion method was used to check the antimicrobial activities of the volatile oil extract. Nutrient agar of about $30 \mathrm{~mL}$ in different Petri dishes was swabbed via a $24 \mathrm{~h}$ subcultured bacteria, which were prepared in dilution to match the turbidity intensity of the McFarland standard. Wells (6 mm diameter) were punched in the agar and filled with $10 \mu \mathrm{L}$ of different concentrations $\left(100,80,60\right.$, and $\left.40 \mu \mathrm{gmL}^{-1}\right)$ obtained from the stock solution prepared by dissolving $20 \mathrm{mg} / \mathrm{mL}$ of the volatile oil (VO) in Dimethyl Sulfoxide (DMSO). The plates were incubated at $37^{\circ} \mathrm{C}$ for $24 \mathrm{~h}$. The antibacterial and antifungal activities were accessed by measuring the zone of inhibition in diameter $(\mathrm{mm})$ around the well. DMSO was used as a negative control.

2.4.2. Determination of the Minimum Inhibitory Concentration (MIC) and Minimum Bactericidal/ Fungicidal Concentration (MBC/MFC).

Determination of the MIC was carried out using the micro-tube dilution method according to the method described by Collin et al. [32]. A dilution series of the extract, ranging from 20-100 $\mathrm{gmL}^{-1}$, were prepared and then transferred to the broth in micro-tube. Before 
inoculation of the test organisms, the bacterial and yeast strains were adjusted to 0.5 McFarland. Each micro-tube was labeled appropriately and incubated at $37^{\circ} \mathrm{C}$ for $18-24 \mathrm{~h}$ for bacteria and $25^{\circ} \mathrm{C}$ for $48 \mathrm{~h}$ for the yeast cultures. The MIC values of the extracts were described as the lowest concentration that exhibited no noticeable growth when put side by side with the control containing no extract as the antimicrobial agent. The minimum bactericidal concentration (MBC) and minimum fungicidal concentration (MFC) were determined by plating samples from clear micro-tubes showing no growth onto Mueller Hinton Agar and potato dextrose agar (PDA), respectively. MBC and MFC were defined as the lowest concentration yielding negative subculture. Both Ciprofloxacin and Ketoconazole were used as the standard antibacterial and antifungal agents (positive control) [33].

\subsection{Antimalarial activity and cell cytotoxicity.}

Investigation into the toxicity of the volatile oil of $X$. aethiopica was carried out by using human cervix adenocarcinoma cells (HeLa cells) according to the method described by Keusch et al. [34]. The volatile oil $(20 \mathrm{mg} / \mathrm{mL})$ was prepared in DMSO, this was diluted with culture medium to $50 \mu \mathrm{g} / \mathrm{mL}$, and $50 \%$ inhibitory concentration from the dose-response assay was obtained from the single concentration assay of the volatile oil, which greatly decreases parasite viability to less than $20 \%$. In brief, the volatile oil was serially diluted while the concentration capable of inhibiting the $50 \%$ cell viability was ascertained by non-linear regression of the dose-response curve. Cytotoxicity of the volatile oil was determined by incubating the oil in duplicate wells with about $1 \times 10^{4} \mathrm{HeLa}$ cells per well; the duration for the incubation was $48 \mathrm{~h}$ carried out at $37{ }^{\circ} \mathrm{C}$ in $5 \% \mathrm{CO}_{2}$. The number of cells that outlived exposure to the volatile oil was found by employing resazurin-based reagent through resorufin fluorescence reading inside the multi-well plate reader. The viability was obtained by comparing the resorufin fluorescence reading of the compound in treated wells with untreated control [35].

The $p L D H$ assay, as described by Makleret et al. [36], was used for the antimalarial determination; the stock solutions for the screening of the volatile oil extract against malaria parasites were carried out the same way as described in the cytotoxicity assay. Fifty $(50 \mu \mathrm{g} / \mathrm{mL})$ of the oil extract was added with parasite culture in a 96- well plate which was were incubated for $48 \mathrm{~h}$ at $37{ }^{\circ} \mathrm{C}$ in a $5 \% \mathrm{CO}_{2}$ incubator. At the end of the $48 \mathrm{~h}$, the pLDH assay was carried out by removing $20 \mu \mathrm{L}$ of the culture from each well and added to $125 \mu \mathrm{L}$ of a combination of Malstat and nitrotetrazolium blue chloride (NBT)/phenazineethosulphate (PES) solutions in a fresh 96-well plate. The purple color produced when $\mathrm{pLDH}$ is present is determined by absorbance at $620 \mathrm{~nm}$, equivalent to the number of parasites in the well. The extract that can decrease parasite viability appreciably from the single concentration assay is further employed in a dose-response assay to determine IC50 values.

\subsection{Antitrypanosomal activity.}

The efficacy of the volatile oil against the trypanosome parasite was accessed using Trypanosoma brucei brucei (T.b brucei) parasite; the stock solution was also prepared the same way as depicted in the cytotoxicity assay. Fifty $\mu \mathrm{g} / \mathrm{mL}$ of the VO was added to the in vitro culture of T.b brucei in 96-well plates, and the resultant mixtures were incubated for $48 \mathrm{~h}$; the number of parasites that are capable of withstanding the drug contact was calculated by adding 
resazurin based reagent as explained earlier in the cytotoxicity assay. The reagent resazurin is usually reduced to resorufin by living cells. Pentamidine was used as a positive control [37].

\subsection{Statistical analysis.}

Statistical analysis data were analyzed using Microsoft Excel and reported as mean \pm standard deviation of triplicate determinations. In addition to this, the non-linear regression using Prism 5 for Windows, Version 5.02 (Graph Pad Software, Inc) program was used to resolve $\mathrm{IC}_{50}$ from the dose-response curve [38].

\section{Results and Discussion}

\subsection{Volatile oil components of $X$. aethiopica.}

The result of the identified components of the fresh fruit of $X$. aethiopica, the percentage composition, the retention indexes, molecular formula, molecular weight, and similarity index are contained in Table 1. The chromatographic analysis revealed the occurrence of twenty-two constituents in the fruit oil of this plant, amounting to $97.33 \%$. The oil is rich in monoterpenes hydrocarbons $(58.0 \%)$, followed by oxygenated monoterpenes (30.13\%), sesquiterpene hydrocarbons (8.46\%), and fatty acids $(0.74 \%)$. It is evident that the composition of the oil is different both qualitatively and quantitatively, as indicated in Table 1.

The significant quantitative constituents of the volatile fruit oil of this plant are 1, 8cineole (16.73\%), $\beta$-pinene (11.59\%), sabinene (10.76\%), 1R- $\alpha$-pinene $(8.30 \%)$, $\alpha$ phellandrene $(8.34 \%)$, 4-terpineol $(6.96 \%)$ and $\gamma$-terpinene $(6.08 \%)$. Other notable compounds found in the seed oil are 2-carene (4.65\%), germacrene (4.27\%), linalool $(3.02 \%), \gamma$-elemene (2.48\%), $\alpha$-terpineol (2.39\%), and ocimene $(2.10 \%)$. Compounds present in significant amount are terpinolene $(1.99 \%), \alpha$-thujene $(1.41 \%)$, aromandedrene $(1.25 \%)$, etc. 1,8 -cineole is volatile oxygenated monoterpenoid ether with various levels of pharmacological effects, and it's employed as a marker for medicinal volatile oil classification [39], it is also known for its medicinal and flavoring properties [40]. Linalool, one of the volatile constituents of the seed oil of this plant, is accountable for the "intense pepperish taste" of the fresh fruit. A small portion of fatty acid (oleic acid) $0.74 \%$ was also discovered in the fruit oil, oleic acid (a monosaturated omega-9-fatty acid) have several health benefits; it is used as a concentrate in cosmetics, decrease blood pressure, augment fat burning, defend the cell against free radical damage, and put off ulcerative colitis [30]. The result reported above for the fruit oil of $X$. aethiopica in our study is slightly different from what was observed in the analysis of the fruit oil from Togo where it was reported that $\beta$-Pinene (23.6\%), $\alpha$-Pinene (11.0\%), sabinene (9.80\%), germacrene D (8.30\%) and 1,8-cineole (8.2\%) are the major components [28], while in Mali the major components of the fruit volatile oil are $\beta$-pinene $(19.1 \%), \gamma$-terpinene (14.70\%), trans-pinocarveol (8.60\%) and p-cymene (7.30\%). [29], but the present study reveals 1, 8-Cineole (16.73\%), $\beta$-pinene (11.59\%), sabinene (10.76\%) $\alpha$-Phellandrene (8.34\%), 1R- $\alpha$ Pinene $(8.30 \%)$ as the major constituents (Table 1). It could be seen that each oil sample has its compositional pattern different from others and the reason is simply due to the different compositional patterns of volatile oils, which are affected by geographical and climatic conditions [41]. This point is also bolstered by Raphael et al. 2020 [10], who also documented different antioxidant values between $X$. aethiopica of Ghana and that of Nigeria species. 
Table 1. Chemical profile of the Seed oil of X. aethiopica.

\begin{tabular}{l|l|l|l|l|l|l}
$\mathbf{S} / \mathbf{N}$ & Constituents & $\mathbf{R I}$ & $\mathbf{M F}$ & $\mathbf{M W}$ & $\mathbf{S I}$ \% to TC & Percentage (\%) \\
\hline $\mathbf{1}$ & Sabinene & 897 & $\mathrm{C}_{10} \mathrm{H}_{16}$ & 136 & 95 & 10.76 \\
\hline $\mathbf{2}$ & $\alpha$-Thujene & 902 & $\mathrm{C}_{10} \mathrm{H}_{16}$ & 136 & 94 & 1.41 \\
\hline $\mathbf{3}$ & $\beta$-Pinene & 943 & $\mathrm{C}_{10} \mathrm{H}_{16}$ & 136 & 96 & 11.59 \\
\hline $\mathbf{4}$ & 1 R- $\alpha$-Pinene & 948 & $\mathrm{C}_{10} \mathrm{H}_{16}$ & 136 & 97 & 8.30 \\
\hline $\mathbf{5}$ & $\alpha$-Phellandrene & 969 & $\mathrm{C}_{10} \mathrm{H}_{16}$ & 136 & 94 & 8.34 \\
\hline $\mathbf{6}$ & Ocimene & 993 & $\mathrm{C}_{10} \mathrm{H}_{16}$ & 136 & 91 & 2.10 \\
\hline $\mathbf{7}$ & $\gamma$-Terpinene & 998 & $\mathrm{C}_{10} \mathrm{H}_{16}$ & 136 & 94 & 6.08 \\
\hline $\mathbf{8}$ & 2-Carene & 1001 & $\mathrm{C}_{10} \mathrm{H}_{16}$ & 136 & 93 & 4.65 \\
\hline $\mathbf{9}$ & Terpinolene & 1052 & $\mathrm{C}_{10} \mathrm{H}_{16}$ & 136 & 93 & 1.99 \\
\hline $\mathbf{1 0}$ & $1,8-$-Cineole & 1059 & $\mathrm{C}_{10} \mathrm{H}_{18} \mathrm{O}$ & 154 & 88 & 16.73 \\
\hline $\mathbf{1 1}$ & Linalool & 1082 & $\mathrm{C}_{10} \mathrm{H}_{18} \mathrm{O}$ & 154 & 93 & 3.02 \\
\hline $\mathbf{1 2}$ & Trans-para-2-Menthen-1-ol & 1109 & $\mathrm{C}_{10} \mathrm{H}_{18} \mathrm{O}$ & 154 & 84 & 0.55 \\
\hline $\mathbf{1 3}$ & 4 -Terpineol & 1137 & $\mathrm{C}_{10} \mathrm{H}_{18} \mathrm{O}$ & 154 & 93 & 6.96 \\
\hline $\mathbf{1 4}$ & $\alpha$-Terpineol & 1143 & $\mathrm{C}_{10} \mathrm{H}_{18} \mathrm{O}$ & 154 & 94 & 2.39 \\
\hline $\mathbf{1 5}$ & Cis- $\beta$-Terpineol & 1158 & $\mathrm{C}_{10} \mathrm{H}_{18} \mathrm{O}$ & 154 & 85 & 0.32 \\
\hline $\mathbf{1 6}$ & $1,4-$-Dihydro-2-Methylbenzoic acid & 1191 & $\mathrm{C}_{8} \mathrm{H}_{10} \mathrm{O}_{2}$ & 138 & 83 & 2.78 \\
\hline $\mathbf{1 7}$ & (-)-Isopulegol & 1196 & $\mathrm{C}_{10} \mathrm{H}_{18} \mathrm{O}$ & 154 & 83 & 0.16 \\
\hline $\mathbf{1 8}$ & Aromandedrene & 1386 & $\mathrm{C}_{15} \mathrm{H}_{24}$ & 204 & 89 & 1.25 \\
\hline $\mathbf{1 9}$ & $\gamma$-Elemene & 1465 & $\mathrm{C}_{15} \mathrm{H}_{24}$ & 204 & 88 & 2.48 \\
\hline $\mathbf{2 0}$ & Germacrene D & 1515 & $\mathrm{C}_{15} \mathrm{H}_{24}$ & 204 & 87 & 4.27 \\
\hline $\mathbf{2 1}$ & $\alpha$-Caryophyllene & 1579 & $\mathrm{C}_{15} \mathrm{H}_{24}$ & 204 & 95 & 0.46 \\
\hline $\mathbf{2 2}$ & Oleic acid & 2175 & $\mathrm{C}_{18} \mathrm{H}_{34} \mathrm{O}_{2}$ & 282 & 87 & 0.74
\end{tabular}

Note: $\mathrm{SN}=$ serial number, $\mathrm{RI}=$ retention index, $\mathrm{MF}=$ molecular formula, $\mathrm{MW}=$ molecular weight, $\mathrm{SI}=$ similarity index and $\mathrm{TC}=$ targeted compound.

Table 2. Minimum Inhibitory Concentration (MIC) and Minimum Bactericidal/Fungicidal Concentration (MBC/MFC) values $(\mu \mathrm{g} / \mathrm{mL})$ for Xylopia aethiopica fruit oil and the standard drug.

\begin{tabular}{l|c|c|c|c|c|c|c}
\multirow{2}{*}{ Microbial isolates tested } & \multicolumn{2}{|c|}{ Fruit oil (sample) } & \multicolumn{2}{c}{$\begin{array}{c}\text { Ciprofloxacin } \\
\text { (Positive control) }\end{array}$} & $\begin{array}{c}\text { Ketoconazole } \\
\text { (Positive control) }\end{array}$ & $\begin{array}{c}\text { (DMSO) } \\
\text { (Negative Control) }\end{array}$ \\
\cline { 2 - 8 } Escherichia coli & MIC & MBC/MFC & MIC & MBC & MIC & MFC & $0.4 \mathrm{~mL}$ \\
\hline Klebsiella pneumoniae & ND & ND. & 50 & 60 & - & - & $0.4 \mathrm{~mL}$ \\
\hline Pseudomonas aeruginosa & 80 & 90 & 50 & 70 & - & - & $0.4 \mathrm{~mL}$ \\
\hline Salmonella typhi & 80 & 90 & 40 & 50 & - & - & $0.4 \mathrm{~mL}$ \\
\hline Bacillus subtillis & 80 & 90 & 50 & 60 & - & - & $0.4 \mathrm{~mL}$ \\
\hline Staphylococcus aureus & ND & ND & 70 & 80 & - & - & $0.4 \mathrm{~mL}$ \\
\hline Candida albicans & 70 & 80 & - & - & 60 & 70 & $0.4 \mathrm{~mL}$
\end{tabular}

$\mathrm{ND}=$ Not detected, $\mathrm{VG}=$ Visible growth

\subsection{In vitro biological assessment.}

The plant kingdom symbolizes a vast reservoir of medicinally active components with different chemical structures and preventive disease. Volatile fruit oil from $X$. aethiopica was assessed for antimalarial potency against chloroquine-sensitive (CQs) 3D7 P. falciparum, against T.b. brucei, a trypanosome accountable for nagana and cytotoxicity through the human cervix adenocarcinoma (HeLa) cell line. For comparative purposes, the positive control adopted for these assays are chloroquine for P. falciparum, pentamidine for T.b. brucei, and emetine for HeLa cell, and the screening assays were Plasmodium Parasite Dehydrogenase $(p L D H)$ for malaria, T. b. brucei, and HeLa cells. 


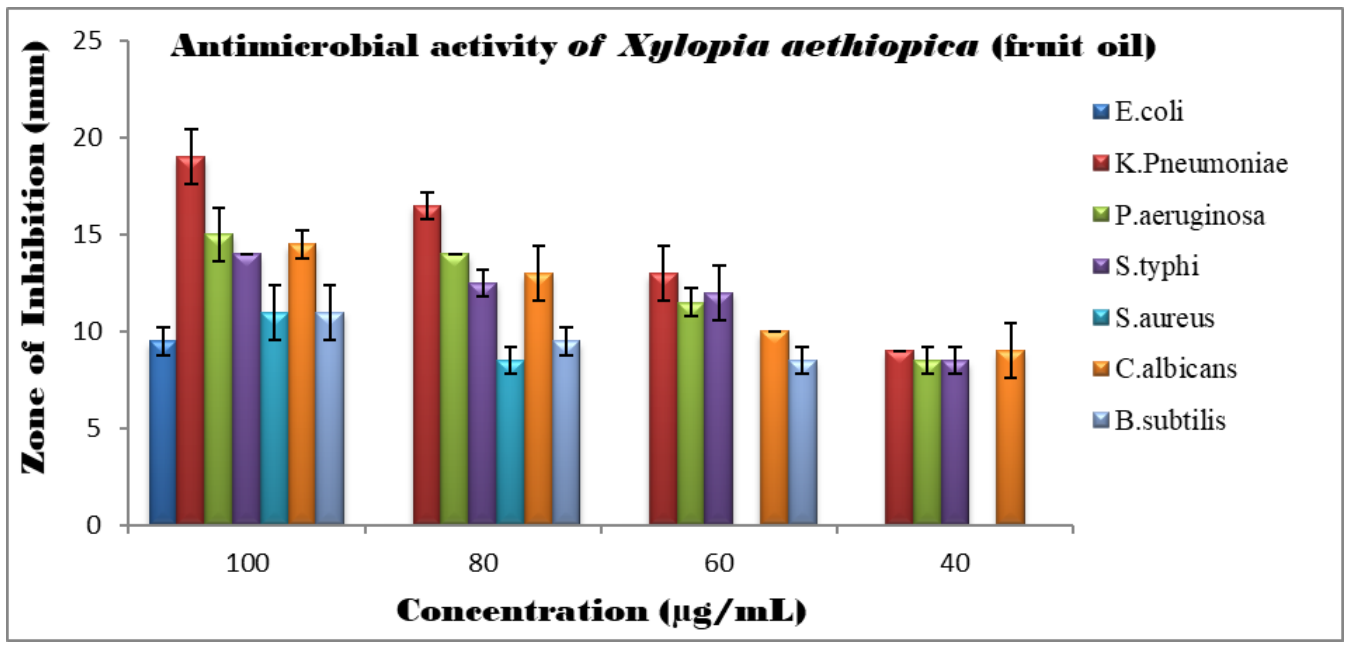

Figure 1. Antimicrobial activity of Xylopia aethiopica.

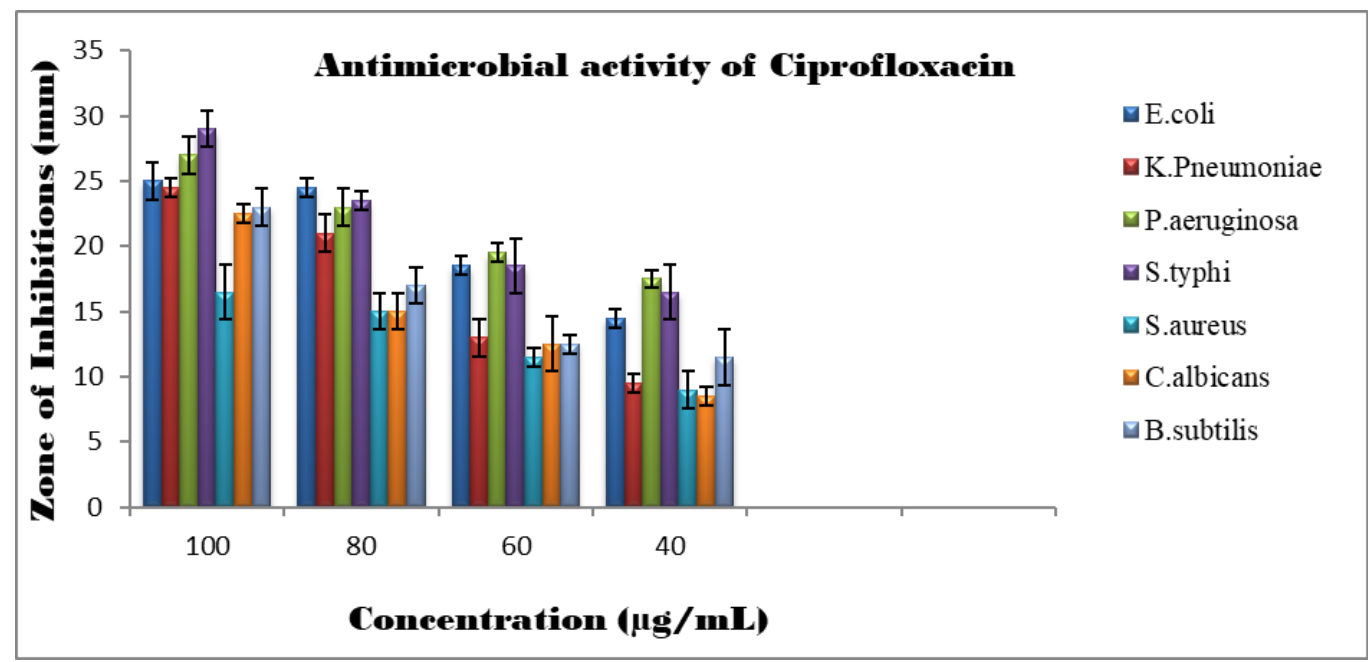

Figure 2. Antimicrobial activity of ciprofloxacin.
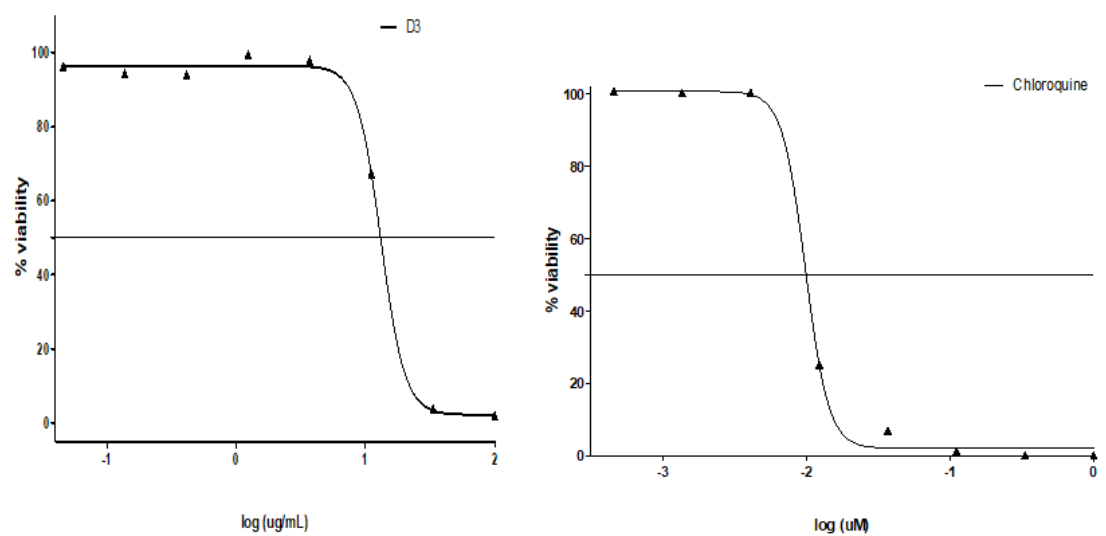

Figure 3. Dose-response assay for $X$. aethiopica and chloroquine.

The volatile oil of $X$. aethiopica only reduced the viability of trypanosomes (T. $b$. brucei) to $83.38 \pm 2.65 \%$, samples or extracts that are not capable of bringing a considerable reduction to about $20 \%$ of the trypanosome parasites are considered not active, therefore the fruit oil of $X$. aethiopica was inactive against trypanosome parasites of $T$. $b$. brucei. Usually, herbal medicine is believed to be safer; for this reason, little research is carried out to test for the safety or toxicity of plant extracts; conversely, the toxicity test was conducted on the volatile fruit oil. The oil showed no cytotoxicity effects because the percentage viability was 
$91.99 \pm 8.31 \%$ as determined by the viability of HeLa cells at a concentration of $50 \mu \mathrm{g} / \mathrm{mL}$, the oil was not capable of reducing the viability of HeLa cells to below 50\%; this might be an indication of their safety as targeted drugs for mammalian organisms while the $\%$ viability of the volatile fruit oil against 3D7 strain of $P$. falciparum was $6.67 \pm 7.74 \%$, this caused a considerable reduction in $p L D H$ activity to less than $20 \%$, the result necessitated the volatile fruit oil to be put forward for $p L D H$ IC50 screening by plotting the $\%$ viability against the volatile oil concentration using a threefold dilution, the IC50 for the oil was generated from the resulting dose-response curve by non-linear regression. The IC50 obtained for the volatile fruit oil was $14 \mu \mathrm{g} / \mathrm{mL}$ showing good activity against the parasite $P$. falciparum. Bero et al. [42] posited that extracts with good activity always demonstrate an IC50 value of less than 20 $\mu \mathrm{g} / \mathrm{mL}$, while extract which displays IC50 in the range of $20-60 \mu \mathrm{g} / \mathrm{mL}$ have moderate activity but those with IC50 above $100 \mu \mathrm{g} / \mathrm{mL}$ are inactive.

The antimalarial activity of this oil may be traced to the various constituents such as monoterpenes hydrocarbons (58.0\%), oxygenated monoterpenes $(30.13 \%)$, sesquiterpene hydrocarbons $(8.46 \%)$, and fatty acids $(0.74 \%)$ found in the crude volatile of the oil since it has been documented by some researchers that terpenes compound are accountable for the antimalarial potencies of many therapeutic plants [43], Schmidt et al. [44] also posited that important class of antiplasmodial natural products are the lower molecular weight constituents of volatile oils (VOs), such as monoterpenes, sesquiterpenes and phenylpropanoids [45], and this can be seen in the volatile fruit oil constituents of $X$. aethiopica Table 1. Consequently, VOs with a high amount of monoterpene constituents usually display antiplasmodial activity [44]. Notably, mechanistic studies have shown that monoterpenes that have low molecular weight like limonene and linalool, and sesquiterpenes, such as farnesol and nerolidol, stalls the biosynthesis of bioactive metabolites like dolichols and the terpenoids side chains of ubiquinones in the trophozoite and/or schizont stages of Plasmodium falciparum [46].

The antimicrobial screening of the volatile fruit oil of this plant as shown in Figures 1 $\& 2$ demonstrates that $X$. aethiopica fruit oil exhibits antimicrobial properties against both Gram-negative, Gram-positive bacteria and the fungus used for this study; in addition to this, the broad spectrum of activities of the microorganisms used was also established, this, therefore, pave the way for a subsequent antimicrobial test such as MIC and MBC/MFC. The volatile fruit oil extract has a significant zone of inhibitions against all the seven test organisms. $K$. pneumoniae had the highest inhibition zone of $19.0 \pm 1.4 \mathrm{~mm}$ followed by $P$. aeruginosa at $15.0 \pm 1.4 \mathrm{~mm}, C$. albicans at $14.5 \pm 0.7 \mathrm{~mm}$ and $S$. typhi at $14.0 \pm 0.0 \mathrm{~mm}$, the least is $E$. coli at $9.5 \pm 0.7 \mathrm{~mm}$. The poor activity recorded for $E$. coli in Figure 2 substantiates previous reports documented by some researchers on the low sensitivity of volatile fruit oil of $X$. aethiopica on Gram-negative bacterium E. coli [25, 28]. The activities of the tested microorganisms compare favorably well with that of the standard antibiotic drug ciprofloxacin. The minimum inhibitory concentration was carried out to ascertain the minimum concentration of the oil that inhibited the growth of the microbes used in this study. The MIC helps determine the level of the resistance of a particular bacteria strain. Same MIC values of ( $80 \mu \mathrm{g} / \mathrm{mL})$ were recorded for $P$. aeruginosa, $S$. typhi, and B. subtillis while the MIC values of $K$. pneumoniae and $C$. albicans were the same $(70 \mu \mathrm{g} / \mathrm{mL})$, showing that they were more active than $P$. aeruginosa, S. typhi, and B. subtillis Table 2. The MBC/MFC was carried out to ascertain whether the volatile oil actually killed the test pathogens or that their growths were only inhibited by the essential oil. The results indicated that $P$. aeruginosa, and $C$. albicans were killed at a concentration of $80 \mu \mathrm{g} / \mathrm{mL}$ while $K$. pneumoniae, S. typhi, and B. subtillis were 
killed at a concentration of $90 \mu \mathrm{g} / \mathrm{mL}$ (Table 2). In traditional settings, several ailments are treated with the aerial parts of X. aethiopica, such as dysentery and biliousness, cough, bronchitis, boils, and sores [12-13]. Documentation from previous researches has shown that $X$. aethiopica exhibits various biological activities like antimicrobial, anti-asthmatic, antiinflammatory, anti-tumor, hypotensive, and coronary effects ascribed to the different secondary metabolites in the plant [47].

The result of MBC/MFC proves that the volatile fruit oil from this plant may be used in therapeutic preparations, especially in the diseases caused by some of these microorganisms as practiced by traditional healers in folkloric medicines. This seems to justify the numerous folkloric medicinal uses of the plant $[10,12-16,19]$.

\section{Conclusions}

This present investigation on the volatile fruit oil of this plant showed that the fruit is a potentially good source of traditional medicine. Because it is a medicinal plant, it has a commercial interest in both research institutes and pharmaceuticals company for the manufacture of new drugs in the treating of various diseases. The result of MBC/MFC proves that the essential oil of this plant can be used in therapeutic preparations, especially in the diseases caused by some of these microorganisms used. In addition to this, the volatile oil from this plant could be used as an excellent substitute to synthetic antiplasmodial and antimicrobial therapeutic drugs to battle malaria and infectious ailment from various bacterial strains.

\section{Funding}

This research received no external funding.

\section{Acknowledgments}

We are grateful to the Centre for Chemico- and Biomedicinal Research at Rhodes University for allowing us to carry out the antimalarial and antitrypanosomal tests of the volatile oil of $X$. aethiopica using South African Medical Research Council (MRC) funds from the National Treasury under its Economic Competitiveness and Support Package. AEMREG, University of Fort Hare, South Africa, is also appreciated for the bacteria strains.

\section{Conflicts of Interest}

The authors declare no conflict of interest.

\section{References}

1. Hosseinzadeh, S.; Jafarikukhdan, A.; Hosseini, A.; Armand, R. The Application of Medicinal Plants in Traditional and Modern Medicine: A Review of Thymus vulgaris. International Journal of Clinical Medicine 2015, 06, 635-642, http://dx.doi.org/10.4236/ijcm.2015.69084.

2. Larayetan, R.; Ololade, Z.S.; Ogunmola, O.O.; Ladokun, A. Phytochemical Constituents, Antioxidant, Cytotoxicity, Antimicrobial, Antitrypanosomal, and Antimalarial Potentials of the Crude Extracts of Callistemon Citrinus. Evid Based Complement Alternat Med 2019, 2019, 1-14, https://doi.org/10.1155/2019/5410923.

3. Mutabingwa, T.K. Artemisinin-based combination therapies (ACTs): best hope for malaria treatment but inaccessible to the needy! Acta tropica 2005, 95, 305-315, https://doi.org/10.1016/j.actatropica.2005.06.009.

4. Williams, H.A.; Durrheim, D.; Shretta, R. The process of changing national malaria treatment policy: lessons from country-level studies. Health Policy and Planning 2004, 19, 356-370, https://doi.org/10.1093/heapol/czh051. 
5. Trape, J.-F.; Pison, G.; Spiegel, A.; Enel, C.; Rogier, C. Combating malaria in Africa. Trends in Parasitology 2002, 18, 224-230, https://doi.org/10.1016/S1471-4922(02)02249-3.

6. Feiz Haddad, M.H.; Mahbodfar, H.; Zamani, Z.; Ramazani, A. Antimalarial evaluation of selected medicinal plant extracts used in Iranian traditional medicine. Iranian Journal of Basic Medical Sciences 2017, 20, 415k,b-422, https://doi.org/10.22038/IJBMS.2017.8583.

7. Maregesi, S.; Van Miert, S.; Pannecouque, C.; Feiz Haddad, M.H.; Hermans, N.; Wright, C.W.; Vlietinck, A.J.; Apers, S.; Pieters, L. Screening of Tanzanian Medicinal Plants against Plasmodium falciparum and Human Immunodeficiency Virus. Planta Med 2010, 76, 195-201, https://doi.org/10.1055/s-0029-1186024.

8. Ugbe, L.A.; Agim, M.; Ada, F.B. An evaluation of the efficacy of extracts from Xylopia aethiopica and Dennittia tripetala in controlling Dermestes maculatus (degeer) an insect pest of dry stored fish in Calabar, Nigeria. J Aquac Mar Biol 2021, 10, 1-6, https://doi.org/10.15406/jamb.2020.10.00301.

9. Sulaimon, L.; Adisa, R.; Obuotor, E.M.; Lawal, M.; Moshood, A.; Muhammad, N. Chemical composition, antioxidant, and anticholine esterase activities of essential oil of xylopia aethiopica seeds. Pharmacognosy Research 2020, 12.

10. Yin, X.; Chávez León, M.A.S.C.; Osae, R.; Linus, L.O.; Qi, L.-W.; Alolga, R.N. Xylopia aethiopica Seeds from Two Countries in West Africa Exhibit Differences in Their Proteomes, Mineral Content and Bioactive Phytochemical Composition. Molecules 2019, 24, https://doi.org/10.3390/molecules24101979.

11. Macedo, T.; Ribeiro, V.; Oliveira, A.P.; Pereira, D.M.; Fernandes, F.; Gomes, N.G.M.; Araújo, L.; Valentão, P.; Andrade, P.B. Anti-inflammatory properties of Xylopia aethiopica leaves: Interference with proinflammatory cytokines in THP-1-derived macrophages and flavonoid profiling. Journal of Ethnopharmacology 2020, 248, https://doi.org/10.1016/j.jep.2019.112312.

12. Erhirhie, O.; Moke, G.E. Xylopia aethiopica: A review of its ethnomedicinal, chemical and pharmacological properties earnest. Am. J. Pharm. Tech. Res. 2014, 4, 22-37.

13. Boampong, J.N.; Ameyaw, E.O.; Aboagye, B.; Asare, K.; Kyei, S.; Donfack, J.H.; Woode, E. The curative andprophylatic effects of xylopic acid on plasmodium berghei infection in mice. J. Parasitol. Res. 2013, 2013, https://doi.org/10.1155/2013/356107.

14. Melo, C.; Perdomo, R.; Yerima, F.; Mahoney, O.; Cornejal, N.; Alsaidi, S.; Coron, S.; Bonnaire, T.; Zhang, S.; Zydowsky, T.M. Antioxidant, antibacterial, and anti-SARS-CoV Activity of Commercial Products of Xylopia (Xylopia aethiopica). Journal of Medicinally Active Plants 2021, 10, 11-23.

15. Ehigiator, B.E.; Adikwu, E. Toxicity study of ethanolic stem bark extract of Xylopia aethiopica on fertility indices of male rats: An experimental study. International Journal of Reproductive BioMedicine 2020, 18, https://doi.org/10.18502/ijrm.v13i4.6889.

16. Bagwai, M.A.; Magashi, A.M.; Bukar, A. Preservative activity of Xylopia aethiopica fruits bio-active fractions on fresh meat. Bayero J P/A Sci 2019, 12, 308-314, https://doi.org/10.4314/bajopas.v12i1.47S.

17. Igwe, S.A.; Afonne, J.C.; Ghasi, S.I. Ocular dynamics of systemic aqueous extracts of Xylopia aethiopica (African guinea pepper) seeds on visually active volunteers. Journal of Ethnopharmacology 2003, 86, 139142, https://doi.org/10.1016/S0378-8741(02)00371-9.

18. Tatsadjieu, L.N.; Essia Ngang, J.J.; Ngassoum, M.B.; Etoa, F.X. Antibacterial and antifungal activity of Xylopia aethiopica, Monodora myristica, Zanthoxylum xanthoxylo1\&\#x0308;des and Zanthoxylum leprieurii from Cameroon. Fitoterapia 2003, 74, 469-472, https://doi.org/10.1016/S0367-326X(03)00067-4.

19. Woode, E.; Abass, A.; Abaidoo, C. Effect of ethanolic fruit extract of Xylopia aethiopica on reproductive function in male rats. International Journal of Pharmaceutical and Biomedical Research 2011, 2, 161-165.

20. Iweala, E.; Bankole, E.; Iheagwam, F.; Dania, O.E.; Ujowundu, F. Cytotoxic Assessment of Xylopia aethiopica [Dun.] A. on Human Prostate and Breast Cancer Cell Lines. 2020, 4, 1143-1146, https://doi.org/10.26538/tjnpr/v4i12.18.

21. Obiri, D.D.; Osafo, N.; Ayande, P.G.; Antwi, A.O. Xylopia aethiopica (Annonaceae) fruit extract suppresses Freund's adjuvant-induced arthritis in Sprague-Dawley rats. Journal of Ethnopharmacology 2014, 152, 522531, https://doi.org/10.1016/j.jep.2014.01.035.

22. Fetse, J.P.; Kofie, W.; Adosraku, R.K. Ethnopharmacological importance of Xylopia aethiopica (DUNAL) A. RICH (Annonaceae)-A review. Journal of Pharmaceutical Research International 2016, 11, 1-21, https://doi.org/10.9734/BJPR/2016/24746.

23. Konning, G.H.; Agyare, C.; Ennison, B. Antimicrobial activity of some medicinal plants from Ghana. Fitoterapia 2004, 75, 65-67, https://doi.org/10.1016/j.fitote.2003.07.001.

24. Tamfu, A.N.; Ceylan, O.; Kucukaydin, S.; Ozturk, M.; Duru, M.E.; Dinica, R.M. Antibiofilm and Enzyme Inhibitory Potentials of Two Annonaceous Food Spices, African Pepper (Xylopia aethiopica) and African Nutmeg (Monodora myristica). Foods 2020, 9, https://doi.org/10.3390/foods9121768.

25. Fleischer, T.C.; Mensah, M.L.K.; Mensah, A.Y.; Komlaga, G.; Gbedema, S.Y.; Skaltsa, H. Antimicrobial activity of essential oils of Xylopia aethiopica. African Journal of Traditional, Complementary and Alternative Medicines 2008, 5, 391-393, https://doi.org/10.4314/ajtcam.v5i4.31295.

26. Adegbenu, P.S.; Aboagye, G.; Amenya, P.; Tuah, B. Susceptibility of bacterial and fungal isolates to spices commonly used in Ghana. Scientific African 2020, 9, https://doi.org/10.1016/j.sciaf.2020.e00530.

27. Asekun, O.T.; Adeniyi, B.A. Antimicrobial and cytotoxic activities of the fruit essential oil of Xylopia aethiopica from Nigeria. Fitoterapia 2004, 75, 368-370, https://doi.org/10.1016/j.fitote.2003.12.020. 
28. Koba, K.; Sanda, K.; Raynaud, C.; Guyon, C.; Chaumont, J.-P.; Nicod, L. Chemical Composition and In Vitro Cytotoxic Activity of Xylopia aethiopica (Dun) A. Rich. (Annonaceae) Fruit Essential Oil from Togo. Journal of Essential Oil Research 2008, 20, 354-357, https://doi.org/10.1080/10412905.2008.9700029.

29. Keita, B.; Sidibé, L.; Figueredo, G.; Chalchat, J.-C. Chemical Composition of the Essential Oil of Xylopia aethiopica (Dunal) A.ch. from Mali. Journal of Essential Oil Research 2003, 15, 267-269, https://doi.org/10.1080/10412905.2003.9712139.

30. Adegbe, A.A.; Larayetan, R.A.; Omojuwa, T.J. Proximate Analysis, Physicochemical Properties and Chemical Constituents Characterization of Moringa Oleifera (Moringaceae) Seed Oil Using GC-MS Analysis. American Journal of Chemistry 2016, 6, 23-28.

31. National Committee for Clinical Laboratory Standards. 1993. Retrieved online from www.nchi.nlm.nih.gov/pmc.

32. Bendig, J. C. H. Collins and P. M. Lyne: Microbiological Methods. 4. Aufl., 521 Seiten, 41 Abb., 70 Tab., Butterworths, London, Boston 1976. Preis: 9,50 £. Food/Nahrung 1978, 22, 440-440, https://doi.org/10.1002/food.19780220412.

33. Khan, M.R.; Kihara, M.; Omoloso, A.D. Antimicrobial activity of Cassia alata. Fitoterapia 2001, 72, 561564, https://doi.org/10.1016/S0367-326X(00)00335-X.

34. Keusch, G.T.; Jacewicz, M.; Hirschman, S.Z. Quantitative Microassay in Cell Culture for Enterotoxin of Shigella dysenteriae 1. The Journal of Infectious Diseases 1972, 125, 539-541, https://doi.org/10.1093/infdis/125.5.539.

35. Cos, P.; Vlietinck, A.J.; Berghe, D.V.; Maes, L. Anti-infective potential of natural products: How to develop a stronger in vitro 'proof-of-concept'. Journal of Ethnopharmacology 2006, 106, 290-302, https://doi.org/10.1016/j.jep.2006.04.003.

36. Makler, M.T.; Ries, J.M.; Williams, J.A.; Bancroft, J.E.; Piper, R.C.; Gibbins, B.L.; Hinrichs, D.J. Parasite lactate dehydrogenase as an assay for Plasmodium falciparum drug sensitivity. The American journal of tropical medicine and hygiene 1993, 48, 739-741, https://doi.org/10.4269/ajtmh.1993.48.739.

37. Larayetan, R.; Ojemaye, M.O.; Okoh, O.O.; Okoh, A.I. Silver nanoparticles mediated by Callistemon citrinus extracts and their antimalaria, antitrypanosoma and antibacterial efficacy. Journal of Molecular Liquids 2019, 273, 615-625, https://doi.org/10.1016/j.molliq.2018.10.020.

38. Rotimi, L.; Ojemaye, M.O.; Okoh, O.O.; Sadimenko, A.; Okoh, A.I. Synthesis, characterization, antimalarial, antitrypanocidal and antimicrobial properties of gold nanoparticle. Green Chemistry Letters and Reviews 2019, 12, 61-68, https://doi.org/10.1080/17518253.2019.1569730.

39. Larayetan, R.A.; Okoh, O.O.; Sadimenko, A.; Okoh, A.I. Terpene constituents of the aerial parts, phenolic content, antibacterial potential, free radical scavenging and antioxidant activity of Callistemon citrinus (Curtis) Skeels (Myrtaceae) from Eastern Cape Province of South Africa. BMC Complementary and Alternative Medicine 2017, 17, https://doi.org/10.1186/s12906-017-1804-2.

40. Small, B.E.J. The Australian eucalyptus oil industry - an overview. Australian Forestry 1981, 44, 170-177, https://doi.org/10.1080/00049158.1981.10674310.

41. Panizzi, L.; Flamini, G.; Cioni, P.L.; Morelli, I. Composition and antimicrobial properties of essential oils of four Mediterranean Lamiaceae. Journal of Ethnopharmacology 1993, 39, 167-170, https://doi.org/10.1016/0378-8741(93)90032-Z.

42. Bero, J.; Beaufay, C.; Hannaert, V.; Hérent, M.F.; Michels, P.A.; Quetin-Leclercq, J. Antitrypanosomal compounds from the essential oil and extracts of Keetia leucantha leaves with inhibitor activity on Trypanosoma brucei glyceraldehyde-3-phosphate dehydrogenase. Phytomedicine 2013, 20, 270-274, https://doi.org/10.1016/j.phymed.2012.10.010.

43. David Phillipson, J.; Wright, C.W. Can ethnopharmacology contribute to the development of antimalarial agents? Journal of Ethnopharmacology 1991, 32, 155-165, https://doi.org/10.1016/0378-8741(91)90113-R.

44. Schmidt, T.J.; Khalid, S.A.; Romanha, A.J.; Alves, T.M.; Biavatti, M.W.; Brun, R.; Costa, F.B.D.; Castro, S.L.d.; Ferreira, V.F.; Lacerda, M.V.G.d.; Lago, J.H.G.; Leon, L.L.; Lopes, N.P.; Amorim, R.C.d.N.; Niehues, M.; Ogungbe, I.V.; Pohlit, A.M.; Scotti, M.T.; Setzer, W.N.; Soeiro, M.d.N.C.; Steindel, M.; Tempone, A.G. The Potential of Secondary Metabolites from Plants as Drugs or Leads Against Protozoan Neglected Diseases - Part II. Current Medicinal Chemistry 2012, 19, 2176-2228, https://doi.org/10.2174/092986712800229087.

45. Nogueira, C.R.; Lopes, L.M.X. Antiplasmodial Natural Products. Molecules 2011, 16, 2146-90, https://doi.org/10.3390/molecules16032146.

46. Rodrigues Goulart, H.; Kimura Emília, A.; Peres Valnice, J.; Couto Alicia, S.; Aquino Duarte Fulgencio, A.; Katzin Alejandro, M. Terpenes Arrest Parasite Development and Inhibit Biosynthesis of Isoprenoids in Plasmodium falciparum. Antimicrobial Agents and Chemotherapy 2004, 48, 2502-2509, https://doi.org/10.1128/AAC.48.7.2502-2509.2004.

47. Fleischer, T.C.J. Xylopia aethiopica A Rich: A chemical and biological perspective. Univ. Sci. Technol. 2003, 23, 24-31.jm 